\title{
3
}

\section{Constructing the Novel}

Delvau believes he can recognize the social strata of Parisian society in flanerie as easily as a geologist recognizes geological strata.

—Benjamin (Arcades, [M9a, 1], 434)

As we have seen in Chap. 2, within the discourse on and debate over State art, two main lines of enquiry have emerged: the first concerned the protracted aesthetically oriented discussions surrounding the need for a rationalization of forms, often through the use of straight lines, simplified decorative patterns, and an adherence to the real; the second voiced the demands for a political reconfiguration of the role played by the arts within the social sphere, to be achieved by placing increased emphasis on the moral message they are expected to articulate when brought into a wider public discourse involving writers, publishers and intellectuals more generally. From different perspectives, we have so far discussed how, since the mid-1920s, the core problem—namely of creating a modern social, cultural and aesthetic system of the arts resting upon new totalitarian State apparatus and of rejecting the individualism upheld by the liberal State-became a prominent bone of contention throughout the 
entire system set up by the Fascist regime in Italy. However, such a broad issue needs to be broken down into several smaller questions addressing, respectively: the aesthetic process of the rationalization of narrative and architectural forms, the syntactical renewal of artistic expression, the emphasis on morality in the arts, and the use of the arts in the process of social modernization that the regime, as a self-professed ethical and omnipotent State, sought to engineer. These conceptual landmarks guided the debate on State art: in what follows, we will analyse them visà-vis the discursive patterns articulated in the novel.

\section{Towards a Fascist Modernity}

From 1926 onwards, prolonged discussions about a possible definition of Fascist modernity — or more precisely about what it meant to be 'modern' according to the doctrine and stance of the Fascist regime ${ }^{1}$ — punctuated many debates in literary, cultural and political journals of various orientations, ranging from politically conservative journals to official Fascist organs, from those at the fringes of the political arena to seemingly neutral publications. ${ }^{2}$ In sum, even though no conclusive definition was arrived at, it was recognized that to achieve this result, the arts would have to function as an integrated system, through what, in the twilight of the regime, Minister Giuseppe Bottai described in his preface to General Director for Antiquities and Fine Arts Marino Lazzari's book of the same name, as L'azione per l'arte ('action for art'), a concerted practical effort to save the national artistic system (Lazzari 1940, X-IX). ${ }^{3}$

It would be beyond the scope of this monograph to enter into a fullscale theoretical discussion about Fascist modernity, since this issue has been dissected by historians as well as by cultural historians. ${ }^{4}$ The need to be modern, or more precisely to be perceived as not lagging behind compared to the great achievements of the other European nations, had dominated the Italian imagination for some time, and had increased in the 19th and 20th centuries as outlined by Emilio Gentile in his 1997 monograph, La grande Italia. Both Emilio Gentile and Jeffrey Herf, discussing the specificities of the Italian and German case respectively, have highlighted the heterogeneity of the phenomenology of the concept of 
modernity under totalitarian rule, where the notion became at once imbued with a desire for renovation - be it in aesthetic, cultural, political or social terms - but also with a deeply reactionary, irrationalist character in similarly aesthetic, social, cultural and political terms (Gentile 2003; Herf 1986). ${ }^{5}$ In a similar vein, Roger Griffin in particular has put forward the idea of 'palingenetic' rebirth as foundational to the understanding of Fascist modernity, whereby he dissects the role played by mythologies and by the imaginary in its construction (2007, 73-74, 187). As an abstract concept, therefore, the 1930s' version of modernity, and of totalitarian modernity, encompassed a wide-ranging set of propositions, which included a drive towards experimentalism, often through technological progress and theoretical debate, and through a simplistic and grandiose-yet utopic - view of the future, which had to be in line not only with the regime's doctrine of the rejuvenation of the Italian nation, but also with Italy's illustrious past, as well as with the country's own reactionary and technocratic views. ${ }^{6}$

This conceptual, clashing plurality can also be very clearly seen in action throughout the debates and polemics centring on the configuration of State art and on the supremacy of one movement over all the others in the ensuing struggle for hegemony, as, for example, in the wars for intellectual hegemony between the Novecento and Futurist movements, both active across literature, architecture and the visual arts and both politically in close dialogue with Mussolini himself. Devoting specific attention to cultural movements, Mark Antliff has conducted a sustained analysis of modernity, modernism and modernization in relation to the arts and architecture. In his analysis, Fascism and modernism are not to be treated as separate categories but rather as propositions in constant dialogical flow, which can neither exist independently nor in opposition to each other (2002, 165). According to Walter Adamson (1993), in fact, the artistic origins of Fascist modernity are to be traced back to the pre-WWI Florentine avant-garde, since they articulate the very same contradictions and oppositions, which would define the cultural politics of the dictatorship over the whole arc of its existence. In a more recent article, Adamson returns to the cultural dynamics of the dictatorship in order to assess which of the movements and their actors (again: Margherita Sarfatti and Novecento ${ }^{7}$; Filippo Tommaso Marinetti and Futurism ${ }^{8}$; Mino Maccari and Strapaese) 
finally won in the competition for artistic hegemony. Adamson concludes that none of them did, all failing in different ways and to varying degrees (2001, 244-45). Jeffrey Schnapp has talked about 'eclecticism of spirit' as far as the regime's take on cultural production is concerned (see also Malvano 1988a). By formulating this definition, Schnapp highlights Mussolini's encouragement of the proliferation of expressions of cultural modernity to be used by the regime as it saw fit: every expression of modernity was legitimate if it was used appropriately and if it performed a useful function $(1993,91)$. We accept the critical assessment that plurality was a key feature of Fascist modernity, and our contention is that no artistic movement either succeeded or failed in gaining hegemony in the race to embody modernity, since they all need to be understood as a concerted system where every part functioned in relation to the others (Cioli 2011, 5-27, 45-56; see Chap. 2 on pluralism and on the definition of the system of the arts).

In addition to recognizing this artistic plurality, we must also briefly discuss a possible definition of modernity, a term which is central to explaining the intellectual context of the ideas under discussion. As far as the regime and its artistic theorization were concerned, modernity was a mixture of innovation and passéism: of new political statements and reactionary and dogmatic thinking paired with the ambition of modernizing the country socially and culturally. ${ }^{9}$ Crucially, however, modernity was seen as a new social, cultural and political configuration, which would not only create an anti-bourgeois, anti-individualist Fascist Man, ${ }^{10}$ but also produce a vision of a future controlled by anti-liberal politics. Emilio Gentile has often stressed the ways in which the anthropological revolution of Fascism has shaped and substantiated the New Man, a psychic and social subject at the same time (2009). The New Man was so in many respects: in terms of a renewed energy, vigour and pragmatism, for instance, but also with regard to the relationship between subjectivity and objectivity which such an individual had to embody, as an aesthetic political statement and as the expression of aesthetic policies $(2009,103)$. In short, with regard to the arts, modernity was a process driven by progressive statements coupled with experimental aesthetics and media technology, increasingly oriented towards the needs of a 'mass' society within the functioning mechanisms of a repressive political apparatus. In relation to the novel and architecture, 
however, modernization involved the structural transformation of the public spheres driven by social projects centring on a set of aesthetic principles associated with the very idea of modernity and championed by State patronage and the publishing industry. ${ }^{11}$

Modernity as theory and modernization as practice were synergic responses to a set of technological innovations geared to transforming the perception of the individual (publishing, cinema and radio being the most obvious examples), which the regime could use as a means of propaganda as well as a means of turning citizens into a collective being, directed by a super-State. ${ }^{12}$ The relationship between those two fieldsmodernity and modernization - and likewise between the novel and architecture, is often based on 'heteronomous as well as autonomous' principles and statements, which allowed for pluralism ${ }^{13}$ within practices, often going beyond the boundaries both of State art and art for art's sake. ${ }^{14}$ Such aesthetic projects, catalysts as they were for the regime's aspirations towards modernity and social modernization, not only exerted strong pressure in the direction of the internationalization of Italian culture but also strengthened the national tradition both at elite and at popular levels by reinforcing politically the collective sense of individual experience, the anonymity of artists and their creations, and the need for a wholesale renewal of the Italian tradition (see Chap. 5).

The heterogeneous configuration of Italian politics regarding the arts under the regime has led scholars to speak of aesthetic 'pluralism', hoping through such a definition to account for (and vindicate) the relative tolerance of the regime towards aesthetic as well as aesthetic/political expressions which, though seemingly heterodox when compared to the official party line, were nevertheless accorded political credibility. ${ }^{15}$ In this regard, the two great debates on State art examined in Chap. 2-the discussion of Fascist art which appeared between 1926 and 1927 in the pages of Critica fascista, and a similar survey published in Primato in 1940 before the $2 \%$ bill—show how modernity was, throughout this period, simultaneously a political and an artistic question. They highlighted right from the beginning the regime's awareness of the importance held by intellectual labour, youth culture, popular culture and the education of the masses for its very survival. ${ }^{16}$ Intellectuals from across the political spectrum took part in these (Anton Giulio Bragaglia, Massimo 
Bontempelli, Giuseppe Bottai, Mino Maccari, Curzio Malaparte, Umberto Fracchia, Alessandro Pavolini, Mario Puccini), a heterogeneous convergence which exemplifies the eclecticism typical of this decade and of the avant-gardes in the 1910s, prior to the imposition of stricter organizational control through State-sponsored exhibitions and acquisitions, public works and investment in urban regeneration which would define the second half of the 1930s (see Chap. 4 for more details, and Chap. 6 on youth culture). Although no definition of State art could be found, there was agreement on some crucial concepts: Fascist art had to be modern and totalizing, but also ethical/moral, so as to be an expression of the New Fascist Man. Art had to be State art because the State was an ethical and corporative ${ }^{17}$ entity, and hence also a moral and a civil entity which created coercive spaces for the individual. This coercion had to contribute to the completion of the Fascist revolution, which was an intellectual and social' revolt. ${ }^{18}$ The arts were crucial in defining the modes of existence of the totalitarian apparatus, especially when functioning as an orchestrated machine ${ }^{19}$ and not simply as a propaganda tool.

The question of this ethical front recurs in the question of modernity, too: art has to speak for a new morality as its first duty, but it also needs to be 'technical' since 'its principal purpose would be this unity of the arts referred to time and again, which the bourgeois revolutions had shattered and which, the argument went, only architecture would be able to restore'. ${ }^{20}$ Above all, however, this discussion of modernity coincided with an invitation to Italian artists to start a process of rationalization of current aesthetic practices, both in terms of formal structures and of thematic concerns, and to consider the moral aspect of artistic creations as foundational to their execution, while at the same time acknowledging the irrational side of creativity (see Chap. 6 for these debates and Chap. 7 for narrative examples). ${ }^{21}$ Novelists in particular were expected to contribute to the creation of a Fascist model of modernity, by producing works championing the values of Fascism or a new morality and by constructing a narrative space which could accommodate 'reality' and a sense of collectivity in place of solipsism and self-referentiality, and which could adopt a prose style that embraced stylistic essentiality and a geometrical organization of plot structures. ${ }^{22}$ This had to be sought in order for the novel to speak to wider, growing and assorted reading publics as 
required by a more modern publishing industry. Likewise, modern architecture had to share with the novel a similar technical desire for rationalized and functional forms, morality and commitment to social integration and a collective ethos, and so contribute theoretically and practically to the modernization of the public sphere.

\section{From Fragmentation to Construction}

The turn of the century saw the rise of the avant-gardes across Europe, with Italy at the vanguard of the Futurist movement in dismantling structures and grammar and fragmenting the novel. ${ }^{23}$ Meanwhile, the book market was expanding in ever more varied directions, encouraging both popular culture and new writing, through the support of publishers such as the Edizioni della Voce, Carabba, Treves, and Sonzogno and the newly founded Mondadori (Tranfaglia and Vittoria 2000, 156-73). Overall, subjectivity was replacing straightforward nineteenth-century objectivity (e.g. realism), whether in heroic and sensationalist or more intimist, memorialistic and solipsistic works. Having said this, while this attitude was evident in popular fiction, Pericles Lewis has convincingly argued that the modernist novels of Conrad, D'Annunzio, Proust and Joyce materialized their consciousness of the crisis of political, ideological and economic systems, such as liberalism and nationalism, by giving space to a wider, factual, if not explicitly historical, dimension, which ultimately provided an external means of decoding internal logics $(2000,4,11)$.

The end of WWI halted experimentation of the avant-gardes and closed down what had been hailed as a new literary beginning by the likes of the Florentine avant-gardes of La Voce and Lacerba, by Renato Serra's quasi-economic analysis of the book market in Le lettere (1913), and by the omnipresent, chameleon-like Futurists. Furthermore, with the Milanese publishers Treves and Sonzogno leading the way, the Italian publishing industry was essentially still in its infancy and there was no consolidated structure at a national level which could help rebuild the novel itself and allow it to reach a wider audience (Tranfaglia and Vittoria 2000, 191-224, see also Borgese 1923, 86-89). ${ }^{24}$ If the 1920s saw the ferment of the Weimar republic in Germany and the rise of New 
Objectivity, in Italy the situation was rather different, dominated as it was by various manifestations of the 'return to order', such as De Chirico's metaphysical painting, the Novecento movement in architecture and the visual arts, and prosa d'arte and elzevirismo in literary writing hailed from the pages of the Florentine literary reviews, La Ronda (1919-1923), and later Solaria (1926-1936) and Letteratura (1937-1947) (Billiani 2013, 849-54). This pervasive and interdisciplinary 'return to order', then, was a return to classically composed forms which did not necessarily map directly onto the novel-if the latter is understood as a form of storytelling or a form that constructs a plot and a story for the reader.

A notable exception to this trend was Giuseppe Antonio Borgese's novel $R u b \dot{e},{ }^{25}$ insofar as it problematized the relationship between subjectivity and politics, between freedom and ideological choice during the tumultuous years of the biennio rosso (red biennium) of 1918-1920. The novel was first published in 1921 by Treves and then reissued by Mondadori in 1928, the year before the publication of Moravia's Gli indifferenti ${ }^{26}$ by Alpes in Rome (see Chap. 7). During the 1920 s, the status of Italian literature had become particularly problematic owing to the sharp separation between a popular literature (supposedly educational, but more often simply propagandistic) and a literature for the elites. ${ }^{27}$ In 1930, Luigi de Crecchio Parladore makes this point explicitly in Il Saggiatore: Julien and Filippo are both marginal characters because they fail to engage with reality constructively. Sorel is a man of action, while Filippo Rubè cannot act and produce social transformation (1930, 'Giuliano Sorel e Filippo Rubè' Gli Esclusi', 1 (1-2): 32-41). Rubè sits on the threshold between the old liberal regime and the new Fascist order. It is a novel about a man, Filippo Rubè, split between two worlds and between action and passivity. It is a realist novel with a strong historical drive, which spans WWI and the Red Biennium. At the beginning of his life, just like in Gadda's Il castello di Udine, ${ }^{28}$ Filippo Rubè is an enthusiastic supporter/advocate of WWI: he sees it as a way of changing the status quo for the better. But he very quickly becomes disillusioned, and after the end of the war, like many men across the country, he struggles to find a place in the new social fabric of the country. His relationship with the socialist movement is equally accidental and lacks any real engagement and commitment. The novel draws a clear connection 
between economic precarity and social frustration, presenting these conditions as a prelude to the dictatorship. In this respect, Rubè is a social novel centred around a very particular individual, an indecisive character who fluctuates between existential ineptitude and social opportunism. Told in four parts and twenty-four chapters, Rubè represented the need for a new Italian novel with a 'constructive' dimension, which rejected the 'frammentismo' of artistic prose. Moreover, it called for a reassessment of the failure of a generation and the need for social and, crucially, political change. It should be also read in relation to the collection of short essays entitled Tempo di edificare published by Borgese two years later, in 1923. Rubè is therefore another novel which marks the need for modernity and modernization, understood as a transformation of the social sphere. Such a shift is necessary to accommodate the needs and aspirations of Filippo, the average man (l'uomo medio) who has intellectual aspirations, but lacks a clear ideological drive. This is a social and political situation which in 1921 was yet to be clearly defined but which will come to an end by the mid-1920s with the regime's consolidation into power after the murder of socialist politician Giacomo Matteotti on 10 June 1924. ${ }^{29}$

In 1923, Lorenzo Viani published Gli ubriachi, a novel about the living conditions of the lower classes, while Federigo Tozzi published Con gli occhi chiusi (1919), Tre croci (1920) and Il podere (1921), a trilogy of modernist texts set in the Tuscan countryside. In 1923, Umberto Fracchia, editor of the leading La fiera letteraria, released Angela, another example of realist narration with a strong, subjective focal point embodied in the viewpoint of the main character (a young woman who has to become a prostitute to protect the son she had with an older and powerful man) from which to dig down into the unforgiving existence lived by the other characters (Zìmolo, Pietro and Emilio), who have no choice but to face a cruel destiny. Fracchia's novel is an interesting example of early 1920s' realism, because it combines a psychological exploration of the humble lives of the individual characters with choral, interweaving narratives that in style are between nineteenth-century feuilletton, late Decadentism and an early return to realism. Every character, from the old Zìmolo to the young Angela or Emilio, follows a typical trajectory of coming of age and at some point acts as an independent self. However, because of their strong links to their historical moment and social milieu, they can only 
be understood in their complexity if we take the whole story as a closely knit system. Fracchia adopts a lucid prose, which is very precise and devoid of excess, to picture both the characters' interiority and the ways in which reality acts upon them. There is no redemption or happy ending for anyone and the lyricism and naiveté of the beginning become bitter disillusionment. Angela is, however, an important example of the coexistence of intimism and realism against the backdrop of a carefully constructed and chronologically consistent plot.

In the same year though, Italo Svevo completed his modernist, experimental masterpiece, La coscienza di Zeno, and Bruno Cicognani finished his bestselling naturalist novel La Velia, thereby showing the variety of narrative performances and styles of the 1920s which were yet to be formalized under the rubric of either the 'Italian, national novel' or the 'return to realism of the $1930 \mathrm{~s}$ ' ${ }^{30}$

The year 1929 saw the cause célèbre ${ }^{31}$ of Gli indifferenti and the beginning of a distinctively anti-bourgeois movement in literature, while the rondista Vincenzo Cardarelli won the Premio Bagutta with his far more conventional Il sole a picco (see Chap. 7). In Moravia's scandalous novel, ${ }^{32}$ the Ardengo family embodied a social problem, a microcosm of collective middle-class indifference, while Leo Merumeci represented a loutish yet successful Fascism. Above all, however, we have a solid diegesis-the Aristotelian unity of time, place and action - as well as a linguistic precision, almost surgical in its eschewal of manneristic psychologism. The failure of Carla and Michele can be seen as a result of their inability to escape from themselves and assume full responsibility in their enlarged social sphere (see Chap. 7 for a detailed analysis).

As this selection of significant, yet diverse, examples suggests, just as was the case in the publishing industry, which lacked a centre and a clear direction, the literary field in the first half of the 1920s was equally divided up between the few remaining elziviristi, for example, Emilio Cecchi (Pesci rossi, 1920), La Ronda, the modernist, europeanist, francophile intimism ${ }^{33}$ of Solaria, the developing naturalist tradition of sensationalist novels and the ever-ebullient pseudo-Futurist underground milieu of the Rome-based avant-gardes of Anton Giulio Bragaglia et al. (Mondello 1990, 67-88). 
The 1930s were the decade of the industrial development of the publishing industry, led by Mondadori, and supported by a regime which needed a 'realist' novel to represent the Italian-Fascist tradition nationally and internationally (Tranfaglia and Vittoria 2000, 249-57). More generally, however, as observed by Paolo Buchignani, the attempt to rebuild the novel is evident not only in the celebrated Gli indifferenti, but also in Corrado Alvaro's Gente in Aspromonte 34 (1931) and in his dystopian novel L'uomo è forte (1938) $(1987,727) .{ }^{35}$ The book was published in 1931 by the Florentine publisher Le Monnier. Set in the author's native Calabria, the narratives delve into the difficult realities of post-unification rural Southern Italian life. The collection's powerful exploration of the poverty, exploitation and injustice endemic to the Italian South renders it one of the finest examples of the return to realism of the 1930s. The eponymous opening story (and the longest, at just a little short of half the length of the whole book) sets the scene and tone of the whole collection. It recounts the desperate plight of the peasant Argirò and his family, left 'by history and reality' to a destiny of poverty and marginalization. Published just two years after Moravia's Gli indifferenti, Alvaro's novel also focused on the everyday reality of its protagonists, but in the radically different setting of one of the most deprived areas of the country. Gente in Aspromonte addressed another crucial issue for the regime: the question of regionalism, which split the art world into two camps (Sabatino 2010, 129-64). On the one hand, there was the ultra-nationalist Strapaese movement led by Mino Maccari, and on the other, the cosmopolitan Stracittà, pioneered by Massimo Bontempelli. From the early 1930s onwards, regionalism was also a bone of contention in architecture, with different schools of thought similarly divided into advocates of the national/regional tradition and those looking at the European scene (see Chap. 4).

As Sabatino observed, Giuseppe Pagano was one of the most ardent admirers of rural architecture (architettura rurale ${ }^{36}$ ). Pagano's understanding of architettura rurale as an antidote to classicizing monumentality was not encumbered by the appeal of rusticity, but instead fuelled his interest in the rational process underlining affordable housing ${ }^{37}$ and the role that industrialization could play' (130). Just like architettura rurale, Gente in Aspromonte responded to the call for a novel which was in touch 
with reality, but also wanted to simplify the narrative structure and language of prose writing in line with Bontempelli's magical realism and that of 900 Alvaro was a regular contributor to. It was also characterized by a firm moral imperative, seeking to bear witness to the harshness of peasant life and to promote social change. The collection deals with the themes of emigration, illness, marginalization, sexuality, social ambition, resentment, resignation and social injustice. Alvaro observed the lives of peasants in the region of the Aspromonte in the documentary style typical of the 1930s, refusing any ornament in a text punctuated by essential dialogical exchanges (again, like Moravia). There is no oneiric evocation of the past in Alvaro's writing. Rather, the hope for a change is a trait d'union across the thirteen short stories. Contrary to previous letteratura meriodionalistica, Alvaro's text had an almost militant ambition coupled with an interest in the mythological dimension that the act of telling can impose on reality: by turning objects and people into universal symbols, his writing was an effort to record and raise awareness of the social condition of those obscured, not seen by history.

Such an ideological aspiration was in line with the idea of modernity as progress, able to change the social sphere, and therefore as part of a wider process of modernization and with the desire of preserving the specificity of the Italian tradition: this theoretical (if not always applied) position was not radically different from Pagano's architettura rurale or the aspiration of the Novecento rationalist moments in architecture. ${ }^{38}$ The characters, from the Argiro family to the prostitute, the priest, the immigrant, la Signora Flavia, Teresina, are all individuals but, at the same time, are part of a collective history. The link between writing, social context and pedagogical/ethical mission was also a prominent theme in the youth culture related to the regime, especially in journals, such as Il Saggiatore, Orpheus, L'Universale and Occidente to which Alvaro contributed as discussed in Chap. 6. Finally, it is important to note that Alvaro's brand of realism was distinct from the experimentalism of the avantgardes; to him the idea of writing as a social construct with a clear moral message was more relevant than any form of writing understood as an experiment in representation.

Having said this, we could argue that this return to the real is pervasive and equally evident in some post-avant-garde fringes, such as the Roman 
immaginismo of 'Bolsheviks' writer Umberto Barbaro ${ }^{39}$ in Luce fredda (1931), or in Dino Terra's realist novels Ioni (1929) and Metamorfosi (1931), or even in Marcello Gallian's anarcho-fascist novel Pugilatore di paese published by Carabba with its impoverished setting and atmosphere, but which nonetheless won the 1932 Premio Mediterraneo and the collection of short stories Comando di tappa (Premio Viareggio, 1934). ${ }^{40} \mathrm{~A}$ new brand of realism was also theorized by the architect, theatre choreographer and theorist of the Manifesto dell'Immaginismo ${ }^{41}$ Vinicio Paladini, or in the works of painter Ivo Pannaggi and in the debates of the intellectual groups revolving around journals such as Interplanetario, I lupi or the overtly Fascist Impero, all championing their anti-bourgeois spirit and willingness to get closer to reality through experimental aesthetic practices. ${ }^{42}$

The year 1933 saw the first three instalments of Garofano rosso, ${ }^{43}$ Elio Vittorini's censored Bildungsroman, published in Solaria (only appearing as a single volume in 1948), while Tre operai by Carlo Brenari, a full-scale call for realist narration, was published in 1934. Between 1933 and 1934, Carlo Emilio Gadda wrote Il castello di Udine, ${ }^{44}$ again published by Solaria edizioni in 1934, which won the Premio Bagutta (1935), while Dino Buzzati completed the Bàrnabo delle montagne ${ }^{45}$ for Treves. The Castello collects prose writings of various inspiration, but which are always experimental and expressionistic in nature. The book is dedicated to the former rondista ${ }^{46}$ Riccardo Bacchelli. From this first publication, Gadda's propensity towards linguistic experimentation, which translates into a grotesque and sarcastic transformation of reality, is already clear. The work's language is such an experiment in distortion that the collection of stories opens with a glossary to help readers navigate the linguistic complexity displayed by the Ingegnere. It is entitled 'Sinossi delle abbreviazioni usate annotando' and it is signed by a certain Doctor Feo Averrois, who introduces himself as the translator of the whole work, thereby adding a meta-literary layer to expand the reach of Gadda's experimental writing. It is, therefore, a highly stratified book, which nonetheless rejects the idea of construction to propose a fragmentation of reality through an expressionistic use of languages, as well as also through a sarcastic view of the everyday reality and aspirations of the bourgeoisie (Barberi-Squarotti 1982, 4934; Guglielmi 1963). And, in this respect, it sits squarely within the expressionistic wave in the development of the twentieth-century Italian novel. 
In 1934, the former Futurist Aldo Palazzeschi published Le sorelle Materassi, ${ }^{47}$ an eloquent but crude exploration of the lives of three sisters and their emotional exploitation, thereby renouncing his previous surrealist, humorous writings. After his Futurist phase, Palazzeschi wrote a book that is again a satire but which is also a dissection of the precarious and miserable lives of those living in provincial Santa Maria a Coverciano near Florence. Three hard-working sisters, who have devoted all their lives to working as embroiderers, eventually find some joy in the arrival of a nephew, who, however, is only interested in exploiting them. Palazzeschi's realism could be placed between that of Verga in the nineteenth century and the intimism of early twentieth-century literature. Within 1930s realism, Le sorelle Materassi pointed towards the domesticity of the provinces not as a locus amoenus but rather as a suffocating space which prevents growth and personal development: Remo, the nephew, is narcissistically preoccupied with his physical health and beauty, which he uses to take advantage of everyone around him. Compared to the values of Strapaese upheld by Mino Maccari, the Tuscan provinces are a place of suffering — without redemption — and are therefore removed from the regime's ideals of ruralism and purity. Palazzeschi paints a realistic portrait of the individual subjectivities of the protagonists, which is transfigured comically to tone down the looming tragedy but, more importantly, to alleviate the feeling of a collectivity in crisis. Palazzeschi's characters are caricatures as we see in the three ladies and their attachment first to their work and then to their young and lively nephew. The nephew represents disempowered subjectivity, unproductive and unethical. In contrast to a nineteenth-century tragedy, the story does not end and remains suspended in a sort of modern 'waiting in vain' for Remo who will never materialize other than in his photograph (see Bo [1958] 1982, 5256-257). Le sorelle Materassi shapes collective identities that can relate neither to each other nor to the external reality in a meaningful way, while also describing the limitations of modernization as well as of ruralism. Palazzeschi's iconoclastic vein turns a seemingly realist novel into a moment of reflection on modernity and modernization and on their inevitable crisis.

Until the mid-1930s, narrative realism, like architecture, could construct and constitute itself within a new artistic morality as well as through 
a new compositional syntax, allowing degrees of variation in experimentalism, detail and topicality, while still focusing on the social aspect of writing. It is worth remembering that from 1929 to 1933, the literary field was split into two camps because of the famous battle between calligrafisti and contenutisti. The former group represented the establishment who wanted to preserve the idea of writing as an act driven by a stylistic mission, while the latter was calling for a prose in tune with the shapes of reality. Gramsci summarizes it very clearly when he dismisses Croce and the calligrafisti idea of the autonomy of the arts by stating that the aesthetic and literary question is a problem of 'the historicity and perpetuity' of the arts ('storicità e perpetuità) to ascertain whether the 'bare fact' ('fatto bruto') has been transformed and has evolved into a work of art. Gramsci is, of course, concerned with the 'purity and autonomy of aesthetic practices', but they can only be comprehended if understood as a result of an ongoing historical development (Gramsci 2014 [1933], Notebook 15 (II): p. 1777). As Massimo Bontempelli too stressed, realism could no longer be understood as a mimetic process, since it had to go hand in hand with the process of myth construction, of the deformation of reality, which was also, coincidentally, one of the requirements of the dictatorship as a religion geared towards the construction of a New Man and citizen and a new society ('Spazio e tempo.' January 1928, L'avventura novecentista, 27, see also Chap. 5). ${ }^{48}$

As Bontempelli, a member of the Italian Academy and co-editor with Pier Maria Bardi of the journal Quadrante, also suggested in a letter to Minister Giuseppe Bottai, the Italian novel needed to be rebuilt on three crucial premises:

\section{Dear Bottai,}

I am not quite sure whether you are aware or not that your conclusions about the so-called 'fascist art' are terribly twentieth-century, in the worst sense of this word.

I am keen to point out to you that my two prefaces and the theoretical excerpts in the 'caravana immobile' in the two issues, rather than being, as it is being reported to you by Malevilparts, the soft Soffici and the many Longanesi, have already outlined a series of ideas that are very detailed: they might be debated, of course, if there is anybody around, who might 
be educated enough as well as in good faith; but they are rather fecund anyway, and as Italian as can be. Let me point them out:

1. My position again aestheticism (decadence of the classical spirit)

2. My position against psychologism (analysm, intimism, Freudianism and so on, decadence of the Romantic Spirit)

3. The Art of Writing when considered in the manner of architecture, and therefore as a modification of the inhabitable world. Hence with the aim of inventing myths and fables for our new times.

Corollary:- antilyricism, antimetrics, antistyle

More:- the condition of cinema in this regard has been assessed

4. The difference between imagination as we see it, and the old "fairy-tale", has been cleared

5. The "avant-garde" mode, which has been judged neurotic and soaked in 'literature' has been overcome. Setting in motion an art for the audience.

6. A clear primacy of Italy in the new civilization: a new Mediterranean revival.

7. Specific consequences (condition of the theatre: orientation of music, and so on...

$[\ldots]$

Faithfully

Yours

Bontempelli ${ }^{49}$

This is a sui generis manifesto of an epoch, but Bontempelli also intended it to be a theoretical and conceptual blueprint going beyond the boundaries of the novel. In order to complete the programme of Fascist art and of Fascist State art, ${ }^{50}$ some things needed to be discarded, such as aestheticism, characterized in terms of the static accumulation of objects, introspection-now seen as psychic stasis-and the rejection of bodily movement as action (and implicitly also that of Bottai's idea of culture as action). What needed to be supported instead was the image of artistic creation and of aesthetic experience as constructive phenomena. Although Bontempelli's letter to Bottai is not dated, we can compare it with writ- 
ings of a similar nature published in Avventura novecentista around 1933-1934, during his collaboration with Quadrante. According to Bontempelli, the regime's aesthetic project entailed the construction of myths and fables. Therefore, Fascist art had to avoid any form of nineteenth-century psychologism or the cerebral, abstract avant-gardism of the early twentieth century, as both were incapable of engaging with the everyday contemporary reality of people's lives. Fascist art should not be individualist but rather directed towards the collectivity, in order to produce a full representation of Mediterranean civilization. Yet, what exactly was it that led Bontempelli to write to Bottai on themes connected with art and the novel and architecture, under the aegis of constructivism (a type of soviet constructivism à la Vinicio Palladini or a type of Immaginism à la Dino Terra, editor of La ruota dentata)? ${ }^{51}$ How could such art be realized? It came about through a series of crucial stages, which involved writers, intellectuals, publishers and politicians.

In October 1932, in the first issue of the Rome-based journal Occidente, founded by Armando Ghelardini but affiliated to the Immaginists and the Casa Bragaglia in Rome, a short note appeared in the regular column on the publishing industry, 'Idee uomini opere attraverso la stampa internazionale':

Book publishing has seen a very noticeable increase in output. The statistical data that I have to hand, taken from the Bollettino delle Pubblicazioni Italiane show that the classes of novels, music and the social sciences alone count for an increase of around a thousand units compared to previous years. The growth in the number of novels is significant. From 1920 to the present, the number of monthly publications has gone from 511 to over 1,500. [...] The total number of book titles printed in Italy has reached 11,949. The number of translations has risen to 1,135. The Libro di Stato experiment, which had made life very hard for publishers, can now be considered complete. $(121)^{52}$

In this short piece, in a rather marginal journal, some key issues emerge regarding the profile of the novel and its relationship with regime's consensus-building programme. According to the anonymous reviewer, the novel is growing both in quantitative and in qualitative terms, together with music and social sciences publications. ${ }^{53}$ From 1922 to 
1943, the number of novels published annually ranged from 6336 in 1922 to 8162 in 1943 . These figures excluded the libri scolastici (school textbooks), which ranged from 554 in 1922 to 381 in 1943. In 1932, we see book production peaking at 12,304 titles, a figure which remains stable until 1941, with 10,762 books published, only to decrease again during the war period. The same can be said for the libri scolastici, with an average of 1300 titles per year throughout the 1930s (Santoro 2008, 392-33). Novels maintained a steady share of around 20\% of the book market from 1922 to 1933 (Santoro 2008, 395). In terms of its market share, then, the novel was not a significant phenomenon in itself. ${ }^{54}$ It assumed a more stable position within the literary field if paired with the social sciences and with the two major singularities of the decade: translations and the libro di Stato (unique textbook for all Italian schools). The Italian novel has a value if compared with other types of books, such as the social sciences, which have an average of 35\% of the book market. Or if we read these figures in more abstract terms, the novel has a 'symbolic' value if placed within the boundaries of the Fascist project of building a State art which comprised also other arts and types of books. Crucially, this project had to involve writers and publishers simultaneously.

In 1932, the now Rome-based L'Italia letteraria (formerly La fiera letteraria led by Umberto Fracchia) published an 'Inchiesta sul romanzo'. Directed from 1929 onwards by writers Giovanni Battista Angioletti and Curzio Malaparte, L'Italia letteraria was, de facto, the official regimesanctioned national newspaper for the arts. Bruno Cicognani, author of the bestseller La Velia, contributed to this debate, reiterating how important it was to build a novel around a solid architecture, while lamenting the fact that many Italian men of letters were excessively individualistic (1932, 4, no. 4 (24 January): 1). The Imaginist Umberto Barbaro, ${ }^{55}$ meanwhile, in his article on Dostoyevsky, stated that the loss of an ethical stance and increasing 'fragmentism' were traits shared by both a certain type of Italian literary production of the time and by Croce's idealism, while he called for a change of direction which could embrace a more constructive narrative mission (1932, 'Nuovi occhi per Dostoievschi.' Il Saggiatore 3, no. 3 (May): 98). In the same vein, the editor-in-chief Angioletti praised the inaugural award of the 1932 Bagutta Prize to Giovanni Titta Rosa for his Il varco nel muro because of his vivid portrayal of 'ordinary people' and 
of their real lives (1932, 'Il premio Bagutta a G. Titta Rosa.' 4, no. 5 (January): 1). ${ }^{56}$

The notion of the arts as a collective social enterprise was similarly and officially endorsed by Minister Bottai in his opening speech given at The Third Arts Exhibition of the Syndicate of Lombardy. ${ }^{57}$ Just as the visual arts had benefitted from the widespread system of exhibitions and art galleries so, albeit in a much lower key, 1927 had seen the first book fair (festa del libro) held in Rome under the auspices of the Ministry of Education. The same period also witnessed a proliferation of literary prizes to support the fortunes and misfortunes of the novel. The Mussolini Prize (Academy of Italy, 1931), the Viareggio Prize (1930) and the Bagutta Prize (commissioned by Fracchia, the former editor of La fiera letteraria, in 1927) were all attempts to fill a gap in the market and to promote well-written, realist and carefully constructed Italian prose, which had the main function of addressing 'modern' and new groups of readers. ${ }^{58}$

From various perspectives (writers, critics, party officials, publishers), it seems evident that the novel was increasingly closely associated with an interdisciplinary outlook, and not merely in avant-gardist or experimental terms, but also in connection with the social sciences, the sciences of a modern society. More explicitly, the novel was becoming associated with State art, in an attempt to create a reading public which would support the regime in its totalitarian objectives. ${ }^{59}$ As in every nationformation process, or in this case the Fascist revolution, which was first officially celebrated in 1932 with the Mostra della Rivoluzione ${ }^{60}$ held at the Palazzo delle Esposizioni, the novel had to occupy in theory, if not in practice, a higher position compared to other artistic genres because it would be instrumental in defining the New Fascist Man, a pivotal element of the Fascist anthropological revolution and, in order to do so, it would have to change its status and profile: it needed to be turned towards the social and become closely connected with the contemporary process of technological transformation. ${ }^{61}$ What, then, was this new regime of the novel?

In his contribution to young and up-and-coming publisher Valentino Bompiani's well-known call for the collective novel along the lines of John Dos Passos's trilogy The 42nd Parallel (1930), 1919 (1932) and later 
The Big Money (1936), Bontempelli dismissed the apocalyptic, selfdestructive novel, fraught with anguish and subjectivism, in the following terms:

And we all remember Berlin Alexanderplatz (by Döblin, who is a cut above the others) which, two years ago swept across Germany and then overflowed as it were onto the whole of Europe. The new German novelists are replacing the old myth of the pedantic German by the myth of the anguished German. (Even France, a few months ago, hailed Céline's Voyage au bout de la nuit). We are thus besieged by a type of literature which proclaims itself as the mirror of the epoch, and which can be summed up by that tetra chord pronounced by one of Fabiano's characters: crime, poverty, lust, fraud. But without any of the forces of redemption, whether individual or social, which lighten the darkness of Dostoyevsky and even that of Zola. ('Romanzo apocalittico.' March 1933, L'avventura novecentista, 169) ${ }^{62}$

Bompiani established his publishing house in 1929. He followed in Mondadori's footsteps but was more innovative in outlook, trying to combine in his catalogue popular literature with more experimental products, and of course with translations of foreign novels from Europe, the US and the Far East. From an ambitious publisher's perspective, and one with distinct echoes of the architectural debate, Bompiani singled out the problematic hiatus between national and international literary production and implicitly called for a collaborative, European effort. He also insightfully stressed the importance of the real in the construction of all literary production which, in order to be useful (i.e. sell), cannot be solipsistically conceived and must instead retain close contact with the materiality of the everyday. He hence aligned the novel with the broader discourse on the arts as a whole and on architecture as a privileged form able to reach the new mass public and build a nation (Ben-Ghiat 2001, 113).

In 1934, Bompiani started a campaign for the collective novel, again inspired by John Dos Passos' trilogy. According to Bompiani, the collective novel had to assume its place as the new Italian novel, and embrace a new brand of verismo aiming at building a new collective consciousness ('Invito editoriale al romanzo.' 14 March 1934, Gazzetta 
del popolo: 3). ${ }^{63}$ The ensuing debate is interesting in many respects: Bontempelli was sceptical regarding the initiative because he saw it as excessively documentary, while other voices expressed doubts about the ability of Italian writers to produce a national novel. Bompiani's vision of, and call for a collective ${ }^{64}$ novel is also important in relation to the wider picture because of his openness towards Europe. He placed Italian literature's existence in relation to other cultural landscapes on a competitive basis, as was also the case for the architectural project and for Bontempelli and 900, since, as a professional, he was rightly aware of the growing success of translations, which overshadowed a still weak national novel (Billiani 2007, 139-40).

\section{Translating the National Novel}

Seen purely as a marketable product, the Italian novel was, arguably, never a major concern for the regime, or at least not in terms of censorial control or mass distribution. Such a situation lasted until 1938, when the racial laws were introduced, and deteriorated during WWII. Hostility towards translations was rather a matter of debate, which opposed foreign texts in favour of authentic Italian novels (Billiani 2007, 141-43). Censorship was exercised with care, preferably before publication and in agreement with the publishers themselves, and it started to be systematized only in 1934 and later in 1937 with the establishment of the Ministry for Popular Culture (Ministero della Culture Popolare) (Fabre 1998, 18-39). The reason for such a delay in taking official action against foreign influence was that the Italian novel as such never managed to reach a wide enough audience to become a visible problem, and was never in a sufficiently culturally hegemonic position to be able to disseminate values that contradicted those promulgated by the regime; translations, however, were in such a position. Yet, if the regime treated translations, like the novel, with 'tolerant indifference', at least until 1938, and the racial laws, in public it sought to appear distinctively less laissez-faire in this respect. Gramsci's analysis of the literary market provides one possible explanation for this attitude. Wondering why readers preferred foreign texts, Gramsci argued that Italian literature was incapable of creating 
a communication channel between the leading and the subaltern classes. This type of communication was, much in evidence in foreign works, and this also accounted for their economic success (I quaderni del carcere, Notebook 21 vol. 3, (XVII, 1934-35), 2108 and ibid., vol. 3, Notebook 19, (X), 2116-120). Gramsci also suggested that Americanism fostered a new model of realism able, through the use of a shared language, to transform a literary country into a literary nation. The national novel, incapable of speaking to the middle classes, who craved realistic well-written adventures, could now help out an industry which complained of being in a continuous state of crisis - even if the libro di Stato had kept Mondadori afloat. The publishing industry was increasingly becoming an important ally for the regime as it was able to provide the link with the masses that it increasingly needed, especially as the 1930s went on, and it sought to construct a panopticon-like controlling State apparatus.

The novel needed to sell, and the 'scandal' novels of Guido Da Verona and Pitigrilli were the Italian bestsellers of the early twentieth century, yet the success of foreign novels would continue uninterrupted until the end of the regime because these books filled a gap in national production insofar as they told realistic stories with captivating, modern plots, and also put forward an ethical message, however dubious this might be, which could bring readers together (Tranfaglia and Vittoria 2000, 314-16). The Italian bestsellers were often sensationalist, page-turning stories or biographies: Mammiferi di lusso (1920) by Pitigrilli, Il giornalino di Gian Burrasca (1920) by Vamba, Storia di Cristo by Papini (1921), Le scarpe al sole by Paolo Monelli (1921), La Velia by Bruno Cicognani (1921), Il mestiere di marito by Lucio D’Ambra, Mussolini by Giorgio Pini (1926), the bestselling Dux by Margherita Sarfatti (1926), Piccolo alpino by Salvator Gotta (1926), Ma che cosa è questo amore by Achille Campanile (1927). A print run of 20,000 was enough to make a novel a bestseller. As for translations, the bestsellers of the 1930s were the novels published in Mondadori's 'Medusa' series, with a bestselling print run, followed by the 'Romanzi della Palma' (1932-1943) with their exotic locations, risqué illustrations and seemingly neutral stories set amongst social and cultural contexts that were profoundly different from Fascist Italy, and their low price. ${ }^{65}$ The 'Medusa' (1931-1977) and 'Biblioteca 
Romantica' (1931-1942) collections embodied exactly what Gramsci had described: high-quality literature with well-assembled plots and clarity of style (see Billiani 2007, 118 for figures regarding translations and individual series). Margaret Mitchell's Gone with the Wind, published by Mondadori in 1937, sold 100,000 copies and former rondista Riccardo Bacchelli's Il mulino del Po, published by Garzanti, achieved similar sales in 1943. Across the whole publishing field, foreign literature was able to provide quality and also popular appeal, and thus reach the elites, common readers, and, also occasionally, the middle classes. ${ }^{66}$ In terms of sales and sustained success, detective stories, $i$ libri gialli, were unrivalled, selling a cumulative total of 10,000,000 copies by 1943 .

It would therefore be rather safe to assume that the novel, as indicated in cosmopolitan Occidente, occupied a relatively marginal position within the Italian literary system of the 1920s and 1930s, which was numerically dominated by translations of elite and popular foreign fiction. The Italian novel, in line with tradition, was nonetheless the privileged means of representing a nation (as had been the case since unification), and therefore could not simply be treated or addressed as a minor phenomenon; on the contrary, it had to be firmly included in the State's propaganda machine as a vessel of true italianità, and this promotion would be carried out through press campaigns, however ineffective these proved in practice. The novel functioned and assumed relevance and meaning when placed within the cogs of the project of constructing a State art, while it exercised a relatively weak influence if taken as a stand-alone venture.

To conclude, as a working definition for our analysis to follow, from the early 1920s until the end of the 1930s, and in the powerful wake of Gli indifferenti, realism was to be understood as a recalibration of the relationship between subjectivity and objectivity as interconnected moments, and as a move towards a rationalization of prose writing as either expressionist linguistic experimentation à la Gadda or as a reduction to 'naturalezza' as suggested by Bontempelli. It was of course no longer possible to take a nineteenth-century view of realism whereby the real was placed solidly in front of the subject-Verga's famous 'clod of earth'-for the real had now entered the realm of the subject, moulding him or her along with itself, in a constructivist process of mutual reshaping. The subject could not stand as a self-sufficient item, whether heroic 
or intimist, for it had become necessary for it to be reconstructed in relation to an objectivity which had, like in a post-expressionist painting, the power almost to penetrate and disfigure the subject. Yet, while subjectivity as a filter of reality was certainly possible in the 1920s with some notable exceptions, as the regime expanded its State patronage of the arts through firmer control mechanisms and press campaigns, the theorization of aesthetic rationalization as a path towards modernity and social modernization changed the balance of the equation. This paradigm shift is visible in many artistic fields from the second wave of Futurism to mural paintings in the early 1930s. Thus_and just like other forms of artistic, visual and literary expression-the novel privileged a literary mode that embraced varying degrees of realism (including magical realism and spiritual realism) and which was oriented towards social matters. Finally, in doing so, it directly mirrored the contemporaneous Fascist architectural project, which sought to rebuild and reconfigure the foundations of the discipline in order to accommodate a social space for the New Collective Man.

\section{Notes}

1. Only formalised in 1932 with the publication of the Doctrine of Fascism and the Italian Encyclopaedia.

2. The debate on Fascism and modernity has been discussed in detail elsewhere, but for a persuasive analysis of its cultural specificities concerning literature, the visual arts, cinema and the role of literary journals, see Adamson (1993), Ben-Ghiat (2001), Cioli (2011), Tarquini (2011).

3. For more details on this specific debate, see Chap. 2. The idea of art as action was also a constant preoccupation for the Futurists since their early days; see, for example, the manifesto 'Ricostruzione futurista dell'universo', signed by Giacomo Balla and Fortunato Depero and published in Milan on 15 March 1915.

4. We refer back to the critical discussion about critical contributions to the definition of 'Fascist culture' or culture under a dictatorship in the introductory chapter.

5. In this regard, David Roberts has explained that the modernist dimension of art should not be intended simply as an attempt to tame the 
irrational and romantic tendencies of society through processes of technic and productive rationalization (2011).

6. Key to our argument is the notion of 'multiple modernities' as multiple cultural programmes contributing towards the same result: e.g. modernity in this particular instance (Eisenstadt 2002).

7. http://dialecticsofmodernity.manchester.ac.uk/artefact/117; http://dialecticsofmodernity.manchester.ac.uk/essay/486; http://dialecticsofmodernity. manchester.ac.uk/essay/505

8. http://dialecticsofmodernity.manchester.ac.uk/essay/450

9. Futurism, Novecento, Strapaese, Stracittà, Corporativism, New Urbanism, for example, all these movements belong to this rather vague category in some aspects of their thinking. See Sechi (1984, 34-44) and Parlato $(2000,18)$ for details. See also Chap. 2.

10. http://dialecticsofmodernity.manchester.ac.uk/artefact/143; http://dialecticsofmodernity.manchester.ac.uk/essay/419; http://dialecticsofmodernity. manchester.ac.uk/artefact/106; http://dialecticsofmodernity.manchester. ac.uk/essay $/ 500$

11. This discussion is particularly explicit in the case of architecture, with the case popolari (public housing), colonie estive (summer camps) and railway stations. See Chap. 5 on Quadrante for further examples of such interventions.

12. An interesting discussion regarding this specific point can be found in Cioli (2011, 80-116).

13. http://dialecticsofmodernity.manchester.ac.uk/artefact/111; http://dialecticsofmodernity.manchester.ac.uk/artefact/114; http://dialecticsofmodernity.manchester.ac.uk/essay/376

14. For a discussion of the notions of autonomous and heteronomous practices as far as the avant-gardes and modernism are concerned, see Murphy (1999, 23-33). See also Chap. 2 on this point.

15. For a sustained analysis of arts policies and the structures of the apparatus for State patronage devised by the regime, see Braun (2000) on Mario Sironi; Salvagnini (2000) on the system of the arts; Stone (1998) on national and international exhibitions, and Malvano (1988a) on policies regarding the visual arts.

16. The Decree of February 9, 1942 (D.M. 9. 2.42) rationed the use of paper and forbade any new publications as well as the resumption of those which had been suspended or suppressed.

17. http://dialecticsofmodernity.manchester.ac.uk/artefact/120 
18. See Giovanni Fiorioli della Lena, 1932, 'Individualismo e collettivismo.' Critica fascista 10, no. 6 (1 August): 314-15; Ugo D'Andrea, 1933, 'Politica e arte nella rivoluzione.' Critica fascista 10, no. 5 (1 March): 83-84; Vitaliano Brancati, 1933, 'La prosa nell'Italia moderna.' Critica fascista 11, no. 7 (1 April): 132-33; Gherardo Casini, 1933, 'Elementi politici di una letteratura.' Critica fascista 11, no. 9 (1 May): 161-62.

19. http://dialecticsofmodernity.manchester.ac.uk/artefact/220

20. Salvagnini $(2000,350)$, discussing the article by Mario Tinti, 1928, 'Arte e sindacalismo.' Critica fascista 6, no. 17 (1 September): 328-30. See also by Mario Tinti, 1927, 'Arte di popolo e non arte di Stato.' La fiera letteraria 3, no. 13 (27 March): 1.

21. See further interventions G. B. A, 1932, 'Fascismo e letteratura.' L'Italia letteraria 4, no. 11 (13 March): 1-2; Mario Attilio Levi, 1933, 'Dottrina del fascismo.' L'Italia letteraria 9, no. 8 (19 February): 1.

22. For an extended discussion on these points, especially in relation to Fascism, realism and youth culture, see Chap. 6.

23. See Salaris (1985: 30-35), for a discussion of the nuances of Marinetti's take on prose writing in the early days of the movement.

24. The total number of books published in 1926 was 6300 units, compared to 10,000 in 1940 . The maximum was reached in 1932-1933 with a total of about 12,000 books, with the percentage of novels ranging from $7 \%$ to $12 \%$. In absolute terms, the publication of novels went from 617 in 1926 to around 1000 in 1939, peaking in 1933-1935 with almost 1500 titles per year.

25. http://dialecticsofmodernity.manchester.ac.uk/essay/440

26. http://dialecticsofmodernity.manchester.ac.uk/essay/456

27. With Slavia, Frassinelli and Ribet in Turin for high culture, Sonzogno in Milan for popular literature, along with the declining Treves, increasingly replaced by the more modern Mondadori, for middle-brow literature.

28. http://dialecticsofmodernity.manchester.ac.uk/essay/488

29. For a reading of the novel which explores the political and existential themes and divides, see Biasin (1979).

30. It is worth remembering that Joyce published Ulysses in 1922, Mann The Magic Mountain in 1924, Woolf Mrs Dalloway in 1925 and To The Lighthouse in 1927, Döblin Berlin Alexanderplatz in 1929 and Faulkner The Sound and the Fury in the same year.

31. http://dialecticsofmodernity.manchester.ac.uk/essay/456 
32. http://dialecticsofmodernity.manchester.ac.uk/tag/modern-realism

33. http://dialecticsofmodernity.manchester.ac.uk/tag/elite-culture

34. http://dialecticsofmodernity.manchester.ac.uk/essay/437

35. On Alvaro's ability to shape everyday characters which are quite unlike Michele in Gli indifferenti, and thus create a 'national novel' with 'Italian content', see Giorgio Granata, 1932, 'Significato di Alvaro.' Il Saggiatore 3, no. 2 (April): 78-84.

36. http://dialecticsofmodernity.manchester.ac.uk/essay/494

37. http://dialecticsofmodernity.manchester.ac.uk/essay/418

38. http://dialecticsofmodernity.manchester.ac.uk/artefact/18; http://dialecticsofmodernity.manchester.ac.uk/artefact/27; http://dialecticsofmodernity. manchester.ac.uk/essay/514; http://dialecticsofmodernity.manchester.ac.uk/ essay/404; http://dialecticsofmodernity.manchester.ac.uk/essay/417

39. http://dialecticsofmodernity.manchester.ac.uk/essay/454

40. For an account of the selection process and Bontempelli's role, see Enrico Emanuelli, 1932, 'Il Premio Mediterraneo è stato vinto da Marcello Gallian.' L'Italia letteraria 4, no. 19 (8 May): 3.

41. http://dialecticsofmodernity.manchester.ac.uk/essay/495

42. For more details on La ruota dentata, see Carpi (1981, 111-38), while on Gallian, see Bignamini (2012, 133-52, in Cremate 2012) and Bouchard (2009, 39-52, in Marcheschi 2009). The novel Ioni was published just a few weeks before Gli indifferenti by Alpes, and it was influenced by Bontempelli's poetics (Marcheschi 2014, XXV).

43. http://dialecticsofmodernity.manchester.ac.uk/essay/464

44. http://dialecticsofmodernity.manchester.ac.uk/essay/488

45. http://dialecticsofmodernity.manchester.ac.uk/essay/443

46. http://dialecticsofmodernity.manchester.ac.uk/essay/472

47. http://dialecticsofmodernity.manchester.ac.uk/essay/464

48. Dino Buzzati, for example, published two important works which mixed realism and early existentialism in 1935, Il segreto del bosco vecchio, Treves, and in 1940, Il deserto dei Tartari, Rizzoli.

49. Caro Bottai, Non so se tu ti sia reso conto quanto le tue conclusioni circa la cosiddetta 'arte fascista' siano terribilmente 'novecentesche', proprio nell'aborrito senso della parola. Ci tengo anche a farti osservare che le mie due prefazioni, e i brani teorici nella 'caravana immobile' dei due numeri, lungi dall'essere delle 'boutades' come ti van dicendo i Maleparti e i Soffici e altri Longanesi grossi e piccini, hanno già delineato una serie di idee assai precise: discutibilissime sì, se c'è qualcuno abbastanza 
preparato e in buona fede, ma fecondissime in ogni modo, e italiane quanto si può essere. Lascia che te le additi:

1. Posizione contro l'estetismo (decadenza dello spirito classico).

2. Posizione contro lo psicologismo (analismo, intimismo, freudismo, ecc. decadenza dello spirito romantico).

3. L'arte dello scrivere considerata come l'architettura, cioè modificazione del mondo abitabile. Cioè con lo scopo di inventare miti e favole per i tempi nuovi.

Corollario:-antilirsmo, antimetrica, antistile.

Altro:- valutata la situazione del cinema a questo riguardo.

4. Chiarita la differenza tra immaginazione nel nostro senso, e il vecchio 'fiabesco' (antiorientalismo).

5. Oltrepassato l'atteggiamento 'avanguardista', considerato come nevrotico, e imbevuto di 'letteratura'. Avviamento ad un'arte di pubblico.

6. Situazione nettamente preminente dell'Italia nella nuova civiltà: nuova ripresa mediterranea.

7. Conseguenze particolari (situazione del teatro: orientamento della musica, ecc.) $[\ldots]$

\section{Affettuosamente}

Tuo, Bontempelli. (Archivio Mondadori, folder 'Amici e Prs', f. 29, undated typescript.)

50. http://dialecticsofmodernity.manchester.ac.uk/tag/statalization; http:// dialecticsofmodernity.manchester.ac.uk/tag/totalitarian-art; http://dialecticsofmodernity.manchester.ac.uk/hypothesis/1

51. For a fuller discussion on the influence Bottai exercised on Quadrante, see Rifkind (2012, 79-80).

52. 'La produzione libraria è in sensibilissimo aumento. Dai dati statistici che abbiamo sotto mano, forniti dal Bollettino delle Pubblicazioni Italiane, le classi del romanzo, della musica e delle scienze sociali rappresentano da sole un guadagno di un migliaio di unità sugli anni precedenti. L'aumento del numero dei romanzi è significativo. Dal $1920 \mathrm{ad}$ oggi, le pubblicazioni mensili da 511 ammontano ad oltre 1.500. [...] I libri stampati in Italia hanno toccato il totale di 11.949 volumi. Il numero delle traduzioni è salito a 1.135. L'esperimento del Libro di Stato, che aveva messo a dura prova la vita delle aziende editoriali, si può considerare compiuto.' 
53. According to Rundle's calculations, from 1930 to 1935 , the number of translations as a percentage of all published titles increased from $19.19 \%$ to $47.53 \%$. This percentage remained constant until 1941, to decline in 1942 (27.52\%), because of the imposition of a quota (2001: 159).

54. See also, Nicola Perrotti, 1930, 'Perché la letteratura italiana non è popolare in Europa.' Il Saggiatore 1, no. 9 (November): 285-87. Perrotti argued that Italian literature had to become 'modern' and reflect a collective unconscious.

55. http://dialecticsofmodernity.manchester.ac.uk/essay/454

56. Il Saggiatore is also positive about the novel because it reads well 1931, 'Il varco nel muro di G. Titta Rosa.' 2, no. 9 (November): 345-46.

57. Giuseppe Bottai, 1932, 'Arte nel nostro tempo.' Italia letteraria 4, no. 9 (28 February): 1; see also the editorial by G.B.A, 'Fascismo e letteratura.' L'Italia letteraria, cit.: 1.

58. The reading public was slowly growing since the literacy in the country was also on the rise (see Palazzolo 1993: 287-317).

59. Critica fascista published several interventions on the debate on the novel, such as Editorial, 1932, 'Esortazione al realismo.' 10, no. 4 (15 February): 61-62; Domenico Carella, 1932, 'Coscienza collettiva e coscienza individuale'; Valentino Piccoli, 'Babbitt o l'uomo standard.' 10, no. 23 (1 December): 448-49 and 456-57; and Domenico Carella, 1933, 'Nostro realismo.' 11, no. 7 (1 April): 133-34.

60. http://dialecticsofmodernity.manchester.ac.uk/essay/466; http://dialecticsofmodernity.manchester.ac.uk/artefact/23; http://dialecticsofmodernity.manchester.ac.uk/essay/492

61. A similar trajectory would be followed by the 1930s incarnation of Futurism in terms of the attention it dedicated to the everyday, such as in advertisements, e.g. in Fortunato Depero's 1932 Campari campaign, and in the aerofuturismo and aeropittura before and during WWII used as a means of propaganda.

62. 'E tutti ricordiamo Berlin Alexanderplatz (di Doeblin, parecchi gradi più su) che due anni sono ha inondato la Germania ed. è poi traboccato un po' per tutta Europa. Al vecchio mito del tedesco pedante, i nuovi romanzieri germanici stanno sostituendo il mito del tedesco angosciato. (Anche la Francia ha esaltato, sono pochi mesi, il Voyage au bout de la nuit di Céline). Così siamo assediati da una letteratura che si proclama specchio dell'epoca, e può riassumersi in quella quadriade dichiarata da un personaggio di Fabiano: delitto, miseria, lussuria, frode. Ma senza gli impeti di redenzione, o individuale o sociale, che accendono il nero di 
Dostoevski e perfino in Zola.' Fabian is the eponymous title of Erich Kästner's 1931 semi-autobiographical novel.

63. See 'Medusa', Corriere Adriatico, 7 April 1934, 'Passaggi a livello. Ancora del romanzo collettivo.' Tribuna, 19 April 1934.

64. http://dialecticsofmodernity.manchester.ac.uk/essay/448

65. These novels sold up to 20,000 copies, see also Billiani (2007, 125-26) for the negotiations with the regime about this risqué series.

66. For further details on the small-scale publishing industry, especially in relation to translations and the book market, see Tranfaglia and Vittoria (2000, 364-79) and Billiani (2007, 137-49).

Open Access This chapter is licensed under the terms of the Creative Commons Attribution 4.0 International License (http://creativecommons.org/ licenses/by/4.0/), which permits use, sharing, adaptation, distribution and reproduction in any medium or format, as long as you give appropriate credit to the original author(s) and the source, provide a link to the Creative Commons licence and indicate if changes were made.

The images or other third party material in this chapter are included in the chapter's Creative Commons licence, unless indicated otherwise in a credit line to the material. If material is not included in the chapter's Creative Commons licence and your intended use is not permitted by statutory regulation or exceeds the permitted use, you will need to obtain permission directly from the copyright holder. 